\title{
Ocean Resources' Ascendancy over African States Friendship Relations: Can UNCLOS Help Resolve Current or Future Maritime Boundary Delimitation Dispute Issues
}

\author{
Djibril Moudachirou \\ Institute of International Law, School of Law, Wuhan University, Wuhan, China
}

\section{Email address:}

jibrilfofana@yahoo.com

\section{To cite this article:}

Djibril Moudachirou. Ocean Resources' Ascendancy over African States Friendship Relations: Can UNCLOS Help Resolve Current or Future Maritime Boundary Delimitation Dispute Issues. Journal of Water Resources and Ocean Science. Vol. 5, No. 1, 2016, pp. 1-13. doi: 10.11648/j.wros.20160501.11

\begin{abstract}
Despite African states massive support to the event of UNCLOS, their envy to possess ocean resources is gradually getting entangled in the implementation of UNCLOS provisions regarding the delimitation of maritime boundaries upon which they can enjoy sovereign rights or claim sovereignty. The complacency of these provisions is enraging African states on their attempts to appropriate maritime resources. These states do adopt divergent interpretations which entail conflicts that negotiations fail to resolve. Moreover, considering that inviolability principle, uti possidetis principle and even the principles of delimitation adopted by the Court to resolve maritime delimitation issues often result on biased outcomes, it is imperious to think about a concrete way to favor negotiation on a win-win basis. While this paper briefly highlights African states' efforts on the realization of UNCLOS, it does find out some attitudes that encourage and complicate friendly neighborhood relations. It therefore suggests stepping forward on cooperating through joint development agreements to explore and exploit maritime resources found on the disputed zones.
\end{abstract}

Keywords: African States, UNCLOS, Maritime Resources, Maritime Boundary Dispute Settlement

\section{Introduction}

Since immemorial time, the sea cause caused curiosity and passion through its mystery and its perfume of adventure. Nowadays, although this interest still exists, it is renewed and enriched by the revelation of countless wealth that the sea contains. Today, every state is concerned by the sea and the resources beneath it. Oceans are considered as a plinth for sustainable development for states. Either coastal or landlocked, states become aware of a growing ascendency that oceans can have on the future. Thus, states are carried away by sea's covetousness so that every coastal state wants to nationalize portions of sea including those beyond its jurisdiction. Hence $70 \%$ of the globe i. e. the sea is no more considered as an open access space. It is considered as a cake to be shared by coastal states. With this in mind, unilateral appropriation or delimitation of maritime zones has been the practice of coastal states before the event of UNCLOS. In addition, more than a cake, it is source of tensions and conflicts between states around world since every coastal state want to get a big share of cake.
In order to codify ocean's usage and stop abusive nationalization of parts of ocean the First United Nations Conference on the Law of the Sea (UNCLOS I) was convened. Through this Conference, every sovereign state is given opportunity to attend the discussions on the new rule that could govern ocean's usage. Few African states attended that Conference since the majority was under the colonization. However, African states massively attended and made great contributions to subsequent Conferences, i. e. UNCLOS II and UNCLOS III which resulted to the final outcome of the new rule governing the current sea usage: United Nation Convention on the Law of the Sea (UNCLOS). From its signature on 10 December 1982 through its entering into force on 16 November 1994, UNCLOS continues to attract states. Actually, UNCLOS counts 166 states parties including the majority of African states. That is to say that states understand that oceans are key to sustaining life on the planet. Moreover, the importance of oceans for sustainable development has been recognized in the outcome documents of various conferences and summits on sustainable development [1]. However, the best 
comprehension of that fact should necessarily pass through the best practice on implementing UNCLOS by states parties because the regime for oceans and seas established by UNCLOS deals with a wide range of issues on ocean affairs and recognizes that the problems of ocean space are closely interrelated and need to be considered as a whole. Although in general UNCLOS' provisions are more or less comprehensive, some of them are ambiguous and vague, left to the interpretations of states. For example, the lack of clarity or the imprecision of provisions relating to EEZ and the CS delimitation constitutes one of the key problems leading to disputes between states. This paper finds out and discusses some of these issues in highlighting African states attitude and practice which does not comply with UNCLOS' provision. The analysis of this practice affirms that African states are stingy in maritime boundary delimitation issues because they give more preference to the economic outcome they could gain from maritime resources exploitation. Therefore, political and military considerations are neglected during negotiations because each party wants to internalize the disputed zone rather than sharing it with its neighbor. Thus the idea of agreeing a practical arrangement to cooperate and manage the resources beneath the disputed zone are ignored or discussed in vain.

\section{Attitude of African States on the Regulation of the Law of the Sea}

By the time the First United Nations Conference on the Law of the Sea (UNCLOS I) was convened, a good number of African states was enduring their dreadful situation of colonization. Even before UNCLOS I, during the time that the issue of 'liberalization of the sea' from the idea of 'the sea appropriation' was dividing Europeans, Africa was in the ascendancy or the imprisonment of the Europeans. Thus, historically it can be noted that the law of the sea was dominated by a few European powers who applied it in their territories, as well as in the colonies they controlled. Once the struggle of 'sea liberalization' triumphed upon 'sea appropriation', the philosophy of open access to seas beyond narrow territorial waters became the new rule of ocean management. This new rule permitted Europeans to explore and scramble to marine resources wherever they could be found until the end of the $19^{\text {th }}$ century. In order to codify this new rule of ocean usage, a conference was convened (UNCLOS I). Considered as an outsider of the long process of development of the international regime designed to regulate the use the seas, Africa was offered an opportunity to participate to that Conference though many African states were still under colonial domination. Unfortunately, among the few states which gained their independence [2] at that time some states [3] refrain from attending the Conference. As result of this situation, African support for the four conventions [4] adopted at that Conference is very low. For instance, 11/54 African states ratified the Convention on the territorial sea and the contiguous zone, 13/54 African states ratified the Convention on the high seas, only 10/54 African states ratified the Convention on the continental shelf and 11/54 African states ratified the Convention on fishing and conservation of the living resources of the high seas. Even though this attitude can be understood by the lack of experience of the majority of African states in the laws governing the sea, the status quo observed through the attitude of African states has detonated the voices of some African diplomats and international law scholars for a reform of the international legal order. These calls added to those of former colonial territories on other continents have been responded during UNCLOS III negotiations since no African states voted against or abstained when UNCLOS was adopted on April 30, 1982. At UNCLOS III, the status quo previously observed had been replaced by the participation of several African intellectual heads and members who made great beneficial contributions to the international community as well as individual state. [5]

\subsection{African States Attitude After UNCLOS}

A decade after the adoption of UNCLOS it can be noticed that the situation has drastically changed in Africa. In fact, despite an economic crisis that Africa was experiencing in the early 1990 s, Africa made the greatest contribution to the coming into effect of UNCLOS in terms of ratifications. By the end of 1992, 26 states (or 48\%) of the then 54 African states had ratified UNCLOS. Many states have enacted their own maritime legislation and most coastal states have declared 200 mile jurisdictional zone either exclusive economic or exclusive fisheries in nature. Moreover, the need to apprehend maritime resources pushed African coastal states to extend their claims over water traditionally recognized as free seas. With this in mind, coastal states are claiming specific maritime areas enclosed by boundaries pertaining to some regulatory competence such as control over fishing or drilling hydrocarbons on the continental shelf. The majority of African coastal states make use of straight baselines. Most states claim a territorial sea of $12 \mathrm{~nm}$ in accordance with Article 3 of UNCLOS whereas the other states claim wider territorial seas although they are all parties to UNCLOS. For instance, from Atlantic Ocean to Indian Ocean there are states which claim 50 mile territorial sea and fishing zone [6] whereas other are claiming just 12 mile territorial sea and fishing zone due to their restricted coastlines with their neighbors [7]. Furthermore, while some coastal states are claiming more, i. e. 200 mile territorial sea and fishing zone [8] there are states that believe that 200 mile EEZ can be regarded as their legal largest possible EEZ right under Article 57 of UNCLOS [9]. In addition, almost 2/3 of the states claim a contiguous zone extending in most cases up to the maximum allowed by Article 33 (2) of UNCLOS, which is $24 \mathrm{~nm}$ from the baselines. Meanwhile, only 9 African states have fulfilled their obligation regarding the depositing of charts and lists of geographical coordinates with the UN Secretary- General. Altogether, 26 African coastal states are involved in claims submission to the Commission on the Limits of the Continental Shelf. 
With the event of UNCLOS and its ratification it is also remarkable that many African states do hesitate to comply with UNCLOS' provisions and implement them. For example, Benin, Somalia, Congo and Liberia are still claiming a $200 \mathrm{~nm}$ territorial sea, and Togo is claiming a $30 \mathrm{~nm}$ territorial sea whereas UNCLOS limits territorial seas to $12 \mathrm{~nm}$. As far as it concerns the contiguous zone, except the Gambia and Sudan which are claiming $18 \mathrm{~nm}$ instead of $24 \mathrm{~nm}$, many African states do not focus on this area of the sea. Perhaps, they already grabbed a large space of territorial sea and there is no need for claiming appropriate contiguous zones. African states' failure to delimit their contiguous zone could be seen as their irresponsibility regarding various enforcement jurisdictions such as immigration, health, sanitary and pollution controls on their waters. Indeed, contiguous zones' delimitations could help African states prevent or combat illegal environmental pollution, drug trafficking, illegal smuggling and piracy that can be qualify as contemporary significant problems for several African states. The regime of EEZ is generally accepted by states parties to UNCLOS throughout the world and African states widely respected the limit of $200 \mathrm{~nm}$. Although several states miss legislations on this maritime zone, they may have simply declared it or even delimited the EEZ boundary with their neighbor. Considering the CS, many African states are willing to enjoy the opportunities of extending their shelf beyond $200 \mathrm{~nm}$ though relatively only few states have specifically incorporated the text of Article 76 of UNCLOS in their national legislation. In addition, some states would have to update their national legislations on CS delimitation in order to adapt them to the exigencies of UNCLOS rather than those of the 1958 Geneva Convention on the CS.

What can be the reasons justifying these attitudes from African states? Does UNCLOS create more problems than it resolves? The main reason of these attitudes could result from the ambiguities of UNCLOS since it leaves states without clear guidance in some issues. And in order to fill the gaps left by UNCLOS states interpret UNCLOS provisions according to their interests.

\subsection{UNCLOS Ambiguities Regarding Maritime Zones' Delimitation}

Regardless of the low rate of African states' participation to UNCLOS III, the lack of consensus on boundary delimitation issues led to evident ambiguities during the drafting of UNCLOS provisions on boundary delimitation. Although UNCLOS offers some guidance concerning the way to delimit maritime areas such as Territorial Sea (TS), Exclusive Economic Zone (EEZ) and Continental Shelf (CS) as well as the rights of coastal states upon these areas, it does remain silent on the preferred method of boundary delimitation. For example, it is true that Article 15 of UNCLOS tries to apprehend the issue of overlapping claims on territorial sea between coastal states by favoring equidistance method with the exception when there is an 'historic title or other special circumstances' on the area in dispute, it has been silent on what 'historic title' or 'special circumstances' could refer to. Also, supposed that we know all the elements that these terms could encompass, could all these elements be taken in consideration while considering these terms? For instance, could economic factor be taken into account like geographical factors or coastal geography in any maritime boundary dispute? Then, the determination of relevant circumstance seems to be an issue in maritime boundary dispute settlement. Thus, though special circumstances play a major role in maritime boundaries delimitation and therefore fundamental in international law, UNCLOS left the burden to states asserting such circumstances to provide evidence of their claims. Interestingly, through judicial decisions and awards it could be contend that special circumstance like geographical configuration of the maritime areas is a given. And for this reason, the ICJ asserted that it is not an element opened to modification by the Court but a fact on the basis of which the Court must effect the delimitation [10].

In practice, the consideration of special circumstances could benefit more African states, particularly the coastal states situated in the western part in the gulf of guinea. Indeed, the western African coast is convex. This concavity poses problems of enclaves to many coastal states when they are confined between two other states. To this, the presence of large number of islands and largely scattered coastlines seem to complicate maritime dispute settlement between states. Thus, the application of equidistance principle without taking into account special circumstances could be detrimental to some African states. Cameroon has remarked that and highlighted that if the Court drew a strict equidistance line, it would be entitled to practically no EEZ or Continental Shelf. To bring the Court to understand its anxiety Cameroon invoked some reasons. For example, Cameroon alleged concavity of the gulf of guinea in general and of its own coastline in particular created its own virtual enclavement which should constitute a special circumstance. After the Court having dismissed this allegation Cameroon found out that the proximity of Bioko Island to its coast should be considered as a special circumstance requiring an adjustment of equidistance line. But once again the Court found this allegation irrelevant since the island in question lies out of the zone to be delimited.

In order to come to an equitable solution concerning the Continental Shelf and the EEZ delimitation, Articles 74 and 83 of UNCLOS call on states to effect this delimitation through 'agreements'. In the case they fail to do so, they should give preference to concrete 'provisional arrangements' under international law for a 'transitional period'. If these provisions are significant in the management of these zones, it is important to notice that they are generally silent on the method to be used for equitable delimitations. Thus, could the terms "an equitable solution" used in the formulation of Articles 74 and 83 presuppose a new "equitable principle" upon which CS and EEZ should be delimited? In other words, does "equitable solution" means "equitable principle"? And if yes, is this new principle different from the one used for territorial sea 
delimitations, i. e. equidistance principle? Could states call for the application of equidistance principle on disputes regarding the CS and EEZ delimitation too? All these questions demonstrate the imprecision and the vagueness of these provisions and give opportunity to states to interpret them according to their interests. And under such interpretations some states could request the application of equidistance/special circumstances method whereas other may claim equitable principle. Hence, the vagueness of these articles is source of disagreement between states in dispute during negotiations. Therefore, divergent point of views between states concerning the interpretation of these provisions generally open the opportunity to a third party, $\mathrm{i}$. e. Court and Tribunals to provide their interpretations. In this way, ICJ seized such an occasion to clarify what the applicable criteria, principles and rules of delimitation are when there are disputes regarding maritime zones with coincidence jurisdictions. Thus, according to ICJ, similarly to the equidistance/special circumstances method developed in the delimitation of territorial sea, "an equitable solution" regarding the delimitation of the CS and the EEZ should be done under the equitable principles/relevant circumstances method. Despite the fact that international courts and tribunal try to redress the vagueness of UNCLOS provisions on EEZ and CS delimitations, the practice of African states does show that these states are not ready to understand the clarifications made by courts and tribunal on UNCLOS gaps. They are rarely satisfied with the decisions and awards of these courts and tribunals though they finally comply with. Like sovereignty on a piece of land, African states are really reluctant to make concession on the flexibility left to them by UNCLOS regarding the scope of provisions on EEZ and CS delimitations. They usually cling on conflicting interpretations and neglect the alternative way offer to them by UNCLOS, i.e. provisional arrangements such as joint development agreement or unitization on disputed zones though these zones contain valuable natural resources. Otherwise, when they think about these arrangements, the negotiations to conclude them are either deadlocked or unfeasible for one party may intend to get 'a lion share' in the detriment of its neighbor. What can be the reasons of such an attitude? Several reasons could explain this attitude. Amongst them economic factor is focused more than political and technologic factors.

\section{Some Explicative Reasons}

Presumably the overwhelming ratification of UNCLOS by African states could be seen as a symbol of awareness of the outcome they could get by being part of the new regime governing the sea. However, this awareness could not be seen as the expression of their will to promote the law of the sea of the international community. Rather, through political, technologic and particularly economic reasons, we could contend that these ratifications do appear like African states readiness to comply with the transformation of the law of sea.

\subsection{Political Reasons}

The direct impact of decolonization is that African states got their independence from colonial powers. Henceforth, they are new sovereign states, equal member of international community like their former colonial powers. These states can attend Conferences and discuss issues relating to the regulation of new international order. Of paramount importance, since many states have been freed from colonization, their number could be meaningful for votes. Moreover, conscious with the big gap of development between these states and their former colonial powers, the modification of previous equilibrium particularly within international organizations could be seen as the first priority. Thus, any issue relating to international economic order becomes the concern of African states. Therefore, due to the economic advantage of the sea, the participation and the contribution of these states to the transformation of the order governing the usage of ocean and seas is no more an issue of negotiation. In this context, it is useful to understand that African states would no more accept laws established without them on their behalf. For example, classical rules relating to the usage of ocean and seas such as limitless freedom of sea and 3 mile width of territorial sea have been contested in order to gain a future from the sea. Conjointly with other developing countries, African states constitute valuable and influential majority [11] to block American, European and soviets decades of rulings on sea usage during Geneva Conference in 1958. And this will has been expressed out by the Peruvian Prime Minister in August 1970 through the following wordings:

Undoubtedly, the balance is favoring us. Qualitatively, our case is better. No one can conscientiously deny that the means to make a living and the welfare of a people are greater than utilitarian purposes. And from the quantitative point of view, the number of developing states is greater by far than the number of industrialized countries. Things being this way, ail we need to do is remain united in the face of the intentions of those big powers that want to impose on us norms that are convenient for them [12].

Another political reason can be related to the exigencies of securing these new states. Once independent the search and the maintenance of national security is the key role of every state. Thus, the new challenge for African states while internalizing parts of seas is to consider the threats which could derive from sea usage. For example, if sea serves international community for transport of indispensable items for our survival, it is also worth mentioning that sea constitutes the lieu of harmful conducts (economic pillage, pollution, piracy and illegal fishing). Therefore, African states also understood that national security considerations do occupy a good place in every national politics. Moreover, in a time the law of the sea restricted territorial sea to $12 \mathrm{~nm}$ with the idea of an open access sea rights and the right to extend the CS beyond $200 \mathrm{~nm}$, these new states seem to be aware of all forms of aggression on seas. And even though they ignore this, they cannot forget the invasion of their 
former colonial powers through ocean. However, if national security has to be understood through military aspects, the need to equip national army is therefore vital in order to defend portions of seas that new states internalized. Remarkably, despite the existence of the will to defend these portions, African states have to improve in this sense since they are facing cruel lack of equipment as well as qualified human resources to carry out this mission.

\subsection{Economic Reasons}

The existence of billions of tons of living and non-living valuable resources that ocean overflows with stimulates the envy from every states to get a portion of sea. African states are aware of this and express they envy to take part to the great competition of exploration and exploitation of ocean's richness. Although they are missing abilities to compete with developed countries as well as some developing countries in the globe, this awareness is really important since they could also benefit from the openness of the high sea at least through fishing. Moreover, article 2 of 1958 High Sea Convention delightfully provides the freedom of high sea [13]. This could help these states protest less about pillage of living resources by industrialized states.

Knowing that terrestrial resources are rare and in order to restrict their foreign dependences on energy supply, African states also understood that the struggle for oceans' internalization constitutes an important economic stake for their survival and their future since off-shore resources (oil and gas, manganese, iron, nickel) exploitation becomes an industrial reality nowadays. The discovery of these resources and their geographical distribution throughout the world seem to be unequal and thus poke up states' covetousness and threaten harmony between neighboring states. Moreover, this covetousness has cooled down with their formulation into conventional law (UNCLOS). For example, the envy of off-shore hydrocarbon exploitation has given birth to the institution of the Continental Shelf and the right of its extension beyond 200nm. Also, the institution of EEZ and the determination of the Area and its resources "common heritage of mankind" can be regarded as the manifestation and the chance given to states to exploit these resources wherever they may be on the oceans. However, despite the considerable progress in codification ocean management UNCLOS's ambiguities attest that ample scope remains to be clarified. Hence, states' practice demonstrates different interpretations of certain provisions of the law of the sea and, therefore, replacing comity by enmity between coastal states.

\section{Do African Coastal States Refer to UNCLOS's Dispute Settlement Mechanisms}

As discussed above, UNCLOS offers some guidance to coastal states in the delimitation of maritime boundaries. UNCLOS mentions that territorial sea delimitation dispute should be done in accordance with article 15, delimitation dispute concerning the EEZ should follow the provision of article 74 and delimitation dispute concerning the Continental Shelf should be done in accordance with article 83. Due to the ambiguities revealed above, African coastal states are facing to delimitations problems. Thus, when delimitation disputes arise between them, the first question to address is how to deal about these provisions? And sometimes the answer to this question results to tensions between these states whereas UNCLOS provides them with tools to respond this question. These tools or mechanisms can be seen through Part XV of UNCLOS.

\subsection{Settlement of Dispute Under UNCLOS}

In order to preserve peace and friendly relationship among states UNCLOS reiterates international community traditional will to settle any dispute by peaceful means. Thus, UNCLOS requires its coastal states members to resolve their disputes by applying Part XV. And in this context article 279 states that:

States parties shall settle any dispute arising between them concerning the interpretation or application of this Convention by peaceful means in accordance with article 2, paragraph 3, of the Charter of the United Nations and to this end, shall seek a solution by the means indicated in article 33, paragraph 1, of the Charter.

In other words, UNCLOS enshrines UN Charter's goal of seeking and preserving peace when the latter states in article 2, paragraph 3 that "all members shall settle their international disputes by peaceful means in such a manner that international peace and security, and justice, are not endangered". What are these peaceful means?

Chapter VI of the UN Charter listed peaceful means like negotiation, enquiry, mediation, conciliation, arbitration and judicial settlement. In addition, states can resort to regional agencies or arrangements, or other peaceful means of their own choice [13]. The formulation of article 33(1) of UN Charter impliedly indicates that the list of peaceful means of dispute settlement is not exhaustive and thus, opens the avenue for interpretation in order to be understood. The only guaranty that it offers is that it absolutely requires states to refrain from any use of force in dispute settlements. Also the free choice of methods of dispute resolutions offered to states by this article does connote that states are not bound to pursue these methods in series. Nevertheless, these methods constitute without much doubt the most frequently used in dispute settlement. Moreover, the application of these methods in series though it is not an obligation upon states, does constitute a rule under UNCLOS. For example, article 283 (1) of UNCLOS states: "When a dispute arises between States Parties concerning the interpretation or application of this Convention, the parties to the dispute shall proceed expeditiously to an exchange of views regarding its settlement by negotiation or other peaceful means (...)".

Such a phrasing of UNCLOS though it does not impose a duty to states parties to resolve their disputes through exclusively negotiation, it does show a preference to resolve disputes through negotiation. Or better, it does impose a duty 
to states in disputes to commence resolving their disputes through negotiation. And in the case negotiations fail, to seek a solution to their dispute by other peaceful means such as inquiry, mediation, arbitration and judicial settlement. Thus, we can say that UNCLOS makes negotiation as a sine qua non condition to the application of any other method of dispute settlement. Interestingly, with particular focus to maritime boundary delimitation, this position has been supported by ICJ in the North Sea Continental Shelf Cases when it states:

The Parties are under an obligation to enter into negotiations with a view to arriving at an agreement, and not merely to go through a formal process of negotiation as a sort of prior condition for the automatic application of a certain method of delimitation in the absence of agreement; they are under an obligation so to conduct themselves that the negotiations are meaningful, which will not be the case when either of them insists upon its own position without contemplating any modification of it [14].

Under this finding of the Court, it could be noted that not only negotiation is a prerequisite to maritime boundary dispute settlement but negotiation should be carried by states in order to end with practical solutions to their dispute. This does imply that negotiation should be done in good faith. In addition this finding could be considered as requiring states to exhaust all the non-binding methods before submitting their disputes to a binding third party method such as arbitration, ICJ, ITLOS also available for them under Section 2 of Part XV of UNCLOS.

\subsection{African States' Preference in Choosing Their Dispute Settlement Method}

Without recalling past African maritime boundary disputes which have been resolved through arbitrations and ICJ, here we will rely on current manifestation of disputes between African states on one hand and invoke some potential disputes which will attract our attentions in the coming decades on the other hand. This could help us not only apprehend the venues through which African states prefer resolve their disputes but more importantly we could also deduce African states practice on seeking maritime natural resources.

\subsubsection{Current African Maritime Boundary in Dispute}

Here we will mention some ongoing disputes between African states on their maritime boundary delimitations and the venues of dispute settlement they have chosen to resolve their disputes.

a The case between Somalia and Kenya.

Global interest for the richness of the Western Indian Ocean has risen over the past decade, affecting the hydrocarbon resources and fish sector in East Africa. Kenya in 2012 leased eight offshore blocks to oil exploration companies. Seven of these are located in a contested area in the Indian Ocean. Thus, by doing so, Somalia contends that Kenya has contravened Somali Law no. 37 which defines Mogadishu's continental shelf, its 200 nautical miles and territorial seas and firmly protests Kenya's behavior. The Somali government even announced it had completed surveys of the disputed area and planned to start issuing offshore oil and gas exploration licenses by 2015 .

Somalia wants that the boundary line in the territorial sea based on a median line as specified in Article 15, since there are no special circumstances that would justify departure from such a line and that, in the EEZ and continental shelf, the boundary on the basis of the three-step process the Court has consistently employed in its application of Articles 74 and 83. Meanwhile, Kenya wants a maritime boundary based on a straight line emanating from the Parties' land boundary terminus, and extending due east along the parallel of latitude on which the land boundary terminus sits, through the full extent of the territorial sea, EEZ and continental shelf, including the continental shelf beyond 200 nautical miles. This map explains the two divergent points of views.

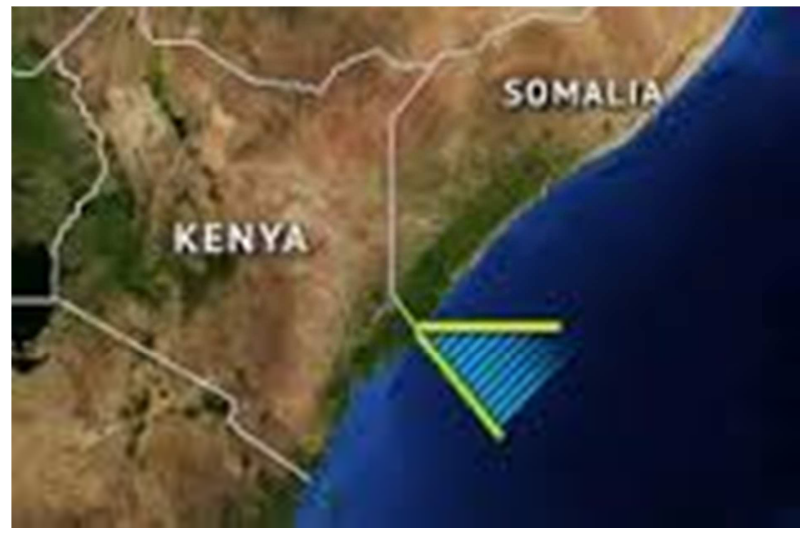

Figure 1. Map showing Kenya and Somalia boundary claims.

Source: http://www.odinafrica.org/news/139-african-maritime-borderdisputes.html.

Therefore, following this divergent point of views on their maritime boundary limits, Somalia seized the ICJ on 28 August 2014 and asks the Court:

to determine, on the basis of international law, the complete course of the single maritime boundary dividing all the maritime areas appertaining to Somalia and to Kenya in the Indian Ocean, including the continental shelf beyond 200 [nautical miles]". The Applicant further asks the Court "to determine the precise geographical co-ordinates of the single maritime boundary in the Indian Ocean [15].

b The case between Ghana and Ivory Coast.

When Ghana found oil in 2007 and began production in 2010 at the Jubilee Field - located in the Atlantic Ocean $60 \mathrm{~km}$ off Ghana shore - Ivory Coast petitioned the U. N. to complete the demarcation of its maritime boundary with Ghana. However, tensions escalated in April 2013, when Ivory Coast announced it had struck oil in an area adjacent to Jubilee Field - Ghana's largest oil field - and sent a correspondence to the government of Ghana casting doubt on the existing median line that divides both countries' waters. The governments of both countries set up a commission in November to come up with technical solutions to end the 
dispute over the area - which reportedly contains reserves of 2 billion barrels of oil and 1.2 trillion cubic feet of natural gas, according to official statistics from both countries [16].

After more than five years of negotiations and many attempts of bilateral conciliation between Ghana and Ivory Coast, these two states have finally decided to submit their maritime boundary delimitation dispute to the arbitration of the International Tribunal for the Law of the Sea (ITLOS) under UNCLOS Annex VII by the end of 2014. Ivory Coast is requesting the Tribunal to order Ghana to suspend any explorations and exploitations activities on an offshore disputed zone which is situated on their international boundary demarcation line. In April 2015, Ghana has been ordered to suspend drilling in waters next to an existing oil and gas field development in the so-called 'ten fields' belonging to Ghana and which are expected to start producing oil by the middle of 2016. The tribunal ruled that any further work in the area would hurt Ivory Coast's interests ahead of a final judgment on where the maritime border lies. However, both countries were ordered to present further evidence and arguments in May in the next stage of the dispute [17], which could last until 2017.

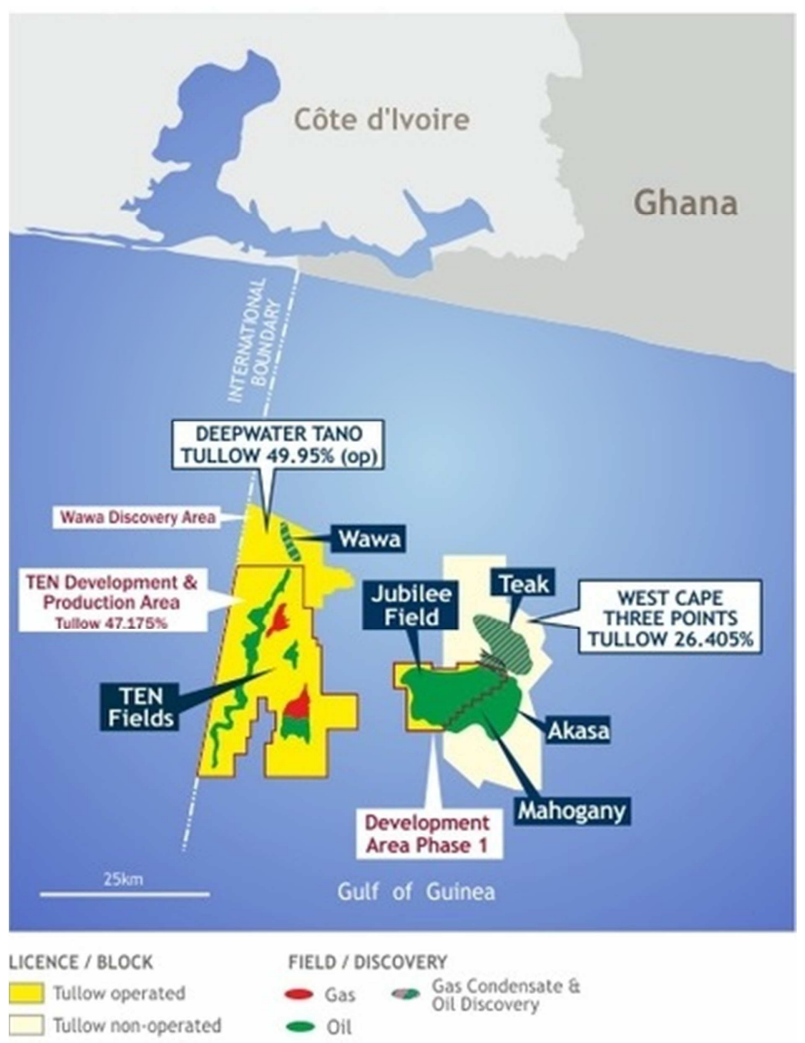

Figure 2. Map showing Ghana and Cote d'Ivoire boundary dispute with regard to oil fields' exploitation.

Source:

http://ressourcesafricaines.blog.lemonde.fr/files/2015/05/Carte_Tullow_Oil_ Ghana1.jpg.

c The case between Democratic Republic of Congo (DRC) and Angola.

The sliver of DRC coastline that reaches to the Atlantic is wedged between Cabinda and Angola proper. Though no specific blocks have been named, the fields most likely to be affected by the dispute are those offshore from mainland Angola's coast and off the southern Cabinda coast, the Angolan enclave just north of the DRC's coastline. Included in this triangle are the Pitanguiera, Safueiro, Bananeira, Sapesapeiro, Essungo and Soyofields offshore Angola's mainland. To the north, the Kambal, Livuite, M'bili, N'tene, Sanzamo N'Kassa, N'dola and Minzu fields also might be affected [18]. These blocks are controversial, however, because the angle at which they are aligned seriously restricts DRC's access to the sea. About $65 \%$ of Angola's petroleum comes from the regions off Cabinda, and DRC has long been claiming that it deserves a portion of the income [19].

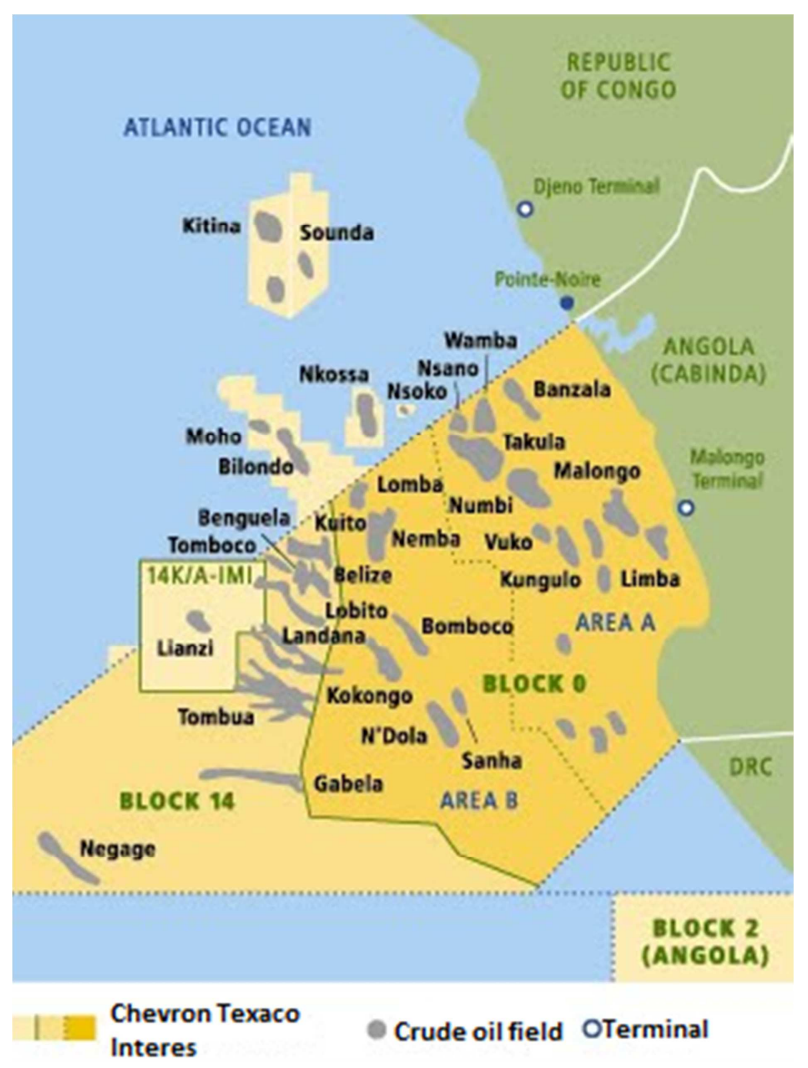

Figure 3. Map showing Angola and DRC boundary dispute.

Source: http://menasborders.blogspot.com/2010/12/border-focus-angolaand-drc.html

After vain temptations to conclude a boundary agreement, these two States began negotiations in May 2003 and signed their first Memorandum of Understanding (MoU) in August 2003. This agreement established joint technical committees mandated to prepare proposals to resolve maritime border disputes. In 2004, the two countries created, in principle, the common interest zone (CIZ) as a new special exploration area [20]. The Angolan government approved this initiative in September 2004 [21], but DRC only did so in November 2007 [22]. Although the DRC ratified the MoU, the decision was not unanimous. Senator Lunda Bululu opposed it because the area and coordinates of the CIZ were imprecise and the members of 
the Congolese Assembly did not have information on the extent of hydrocarbon reserves or the blocks where production was already underway. The MoU was all the more disadvantageous to the DRC because it did not provide compensation for the loss of a share of the royalties already received by Angola from blocks under production. Unfortunately, The CIZ has not resolved the dispute between Angola and the DRC for it is in a standby because the two States are sticking on their divergent points of views.

DRC wants the present maritime space taken from $40 \mathrm{~km}$ off the coast to $200 \mathrm{~km}$, or an expanse of 4,000 square meters, an area that covers the oil zone, where Angola draws 500,000 barrels per day as DRC produces only 20,000 barrels/day. By doing so, DRC aims to receive its fees and take possession of half of oil deposits from two blocks exploited by several multinational companies for Angola. Then, to prevent this, Angola has approved the establishment of an agreement on the delimitation of its maritime borders with DRC on condition that the strict respect of the agreements signed between Portugal and Belgium are taken into consideration. To counter this assumption, DRC had referred to international arbitration by sending a request to the United Nations, for the extension of its continental shelf, within the delimitation of its maritime borders, in accordance with the sea rights. Moreover, it should be noted that both Gabon and DRC are rejecting Angola's proposed changes to the maritime borders, in which Angola seeks to increase its continental shelf length by more than 200mi. Gabon and DRC have written to United Nations secretary-general Ban Ki-moon rejecting part of Angola's 6 December 2013 submission to the UN Commission on the Limits of the Continental Shelf (UN-CLCS).

d The case between Gabon and Equatorial Guinea.

The dispute concerns Mbanie, Cocotiers and Congas, three small islands in CoriscoBay, just north of the Gabonese capital Libreville, near the border with the continental territory of Equatorial Guinea. The dispute has been simmering away quietly since 1972 and has prevented oil companies from carrying out a full exploration of the nearby offshore waters.

However, it came to a head in February 2003, when Gabonese Defense Minister Ali Bongo, actual Gabonese President, visited the Corisco Bay islands and reasserted his country's territorial claim to them. By the way, Nicholas Shaxson, a Berlin-based expert on oil and gas issues in Africa confirmed that "There are fields on both sides of the Corisco Bay area. These wells generally have reserves of several hundred thousand barrels of oil and there are very probably more wells of a similar size here,". In addition, When Ali Bongo visited Mbanie, a 30-hectare island inhabited by a handful of fishermen, and declared it part of Gabon, there was a swift reaction from Equatorial Guinea's Prime Minister Candido Muatetema Rivas said in a radio broadcast: "My government expresses its deep concern and its indignation regarding Gabon's illegal occupation of the small island of Mbanié."

Finally, on 23 January 2004, Equatorial Guinea and Gabon have agreed that a UN mediator should settle their dispute over a handful of small islands that hold the key to potentially oil-rich offshore waters [23]. Still, it should be noted that the establishment of a maritime boundary in hydrocarbon-rich Corisco bay is on stand-by between these two countries because the disputed islands in Corisco bay where the Rio Muni land boundary enters the sea complicate the problem.

\subsubsection{Potential Maritime Disputes Between African States}

Although ICJ helped resolve the dispute between Nigeria and Cameroon the implementation of ICJ's judgment could result in creation of other disputes between some neighboring states. The implementation of this judgment under equidistant line boundary will result in cutting through an oil field licensed by Nigeria. This is the first matter which should be resolved in order to lessen problems from happening throughout the Bakassi peninsula. Then Cameroon will have to address their boundary which has both a lateral aspect between the main land part of Equatorial Guinea, Rio Muni, and an opposite aspect between Cameroon and Equatorial Guinea's Bioko Island. This could also result on a dispute between these states. Furthermore, the equidistantbased boundary lines between Sao-Tome \& Principe and both Equatorial Guinea and Gabon resulted to a slightly overlap zones between these three states due to Equatorial Guinea and Gabon dispute. This could also trigger a dispute if any resource is discovered in this zone.

Another muddling situation can be observed between the Republic of Congo and Gabon since there is no boundary agreement between these two states yet. Moreover, within the Republic of Congo and the Democratic Republic of Congo (DRC) lies the enclave of Cabinda which belongs to Angola, but partly claims by the DRC. This dispute creates many controversies and tensions that spoilt the relationship between Angola and the DRC. Negotiations between these states resulted to a fake memorandum of understanding on resources' exploitation which couldn't be implemented until today. We will discuss this dispute later in the course of this study. For the moment, let's say that there is no formal boundary agreement between these three states whereas potential maritime resources are lying on this area. However, there are unitization agreements that provide for equally shared revenues in this area between Angola and the Republic of Congo while the Democratic Republic of Congo has to fight toughly in order to gain such a deal. In addition, Uganda and DRC continues to dispute over the Rukwanzi Island in Lake Albert and other areas on the Semliki River with hydrocarbon potential.

Farther on the south part of Africa, from the Cape of Good Hope to the Horn of Africa, it is remarkable that although it does have a swift resolution of maritime boundary issues Namibia and South Africa, there are potential disputed islands in the river mouth and both the river itself and the immediate offshore area which are rich in diamonds and oil. Furthermore, it could be noted that South Africa and Mozambique has an incomplete international boundary 
agreement since these two states still have to determine the line of their maritime boundary. And the demarcation of this line could in some extent affect the interest of Madagascar due to its offshore presence in this area. In addition, Madagascar could also be disturbed by the presence of some French islands in this area, notably Ile Juan de Nova and Ile Europa and in some extent Iles Glorieuses which are also claimed by Madagascar. Thus, it will be difficult to guess any maritime boundaries agreement on the Mozambique Channel until the sovereignty issue is settled between France and Madagascar. Moving down to this area, it should be noted that Kenya still have problems to negotiate a maritime boundary with Somalia. Currently, the dispute between these states has been submitted to the ICJ.

The western part of Africa will register some of the most significant maritime boundary disputes due to the preeminent position of the West African coastline on the Gulf of Guinea. Indeed, the location of Benin-Niger-Nigeria tri-point is unresolved and a number of Gulf of Guinea maritime delimitations are yet to be achieved. As far as it concerns the turbulences on maritime boundary issues we can observe that Ghana and Ivory Coast have awaken the dormant situation on which the western part of Africa was by submitting their dispute to ITLOS. And perhaps, these two states did show the way to other states which may be supporting difficult maritime cohabitation with their neighbors on the Atlantic Ocean due to their maritime boundaries which have to be delimited.

A quick check of maritime delimitation cases submitted to ICJ by African states places Africa in the second position with a record of $7 / 22$ cases (or $22 \%$ of all ICJ's cases from 1967 to 2014).

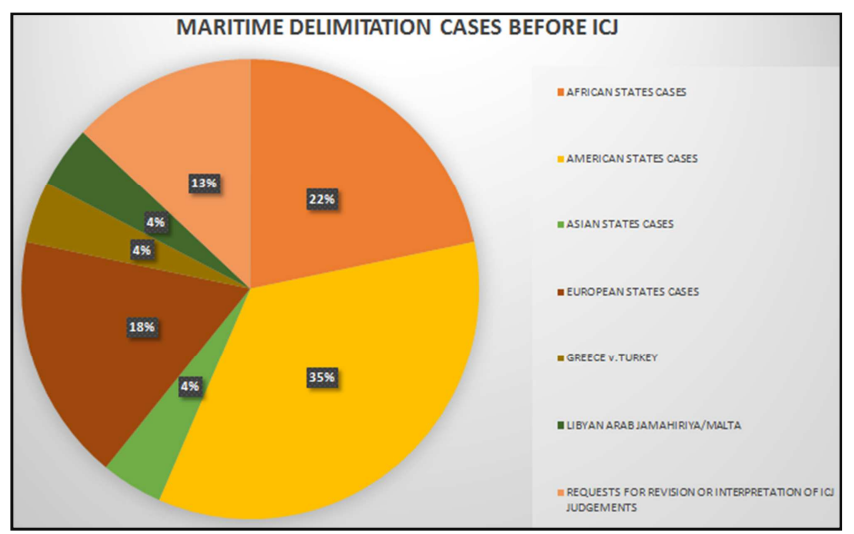

Figure 4. Diagram of comparison of maritime delimitation cases before ICJ.

Although America occupies the first position with 8/22 cases (or $35 \%$ ), it could be permitted to contend that African states are keen on resolving their boundary disputes by judicial means. I wonder whether this avenue could be the best for resolving maritime boundary disputes since African waters are known to be rich in maritime resources. Generally, I think that African states and particularly those in the western part could win more by cooperating and friendly managing this area through practical arrangements rather than exhibiting their disputes to a third party. Moreover, this cooperation could help them conjointly address insecurity and environmental issues on this area since it is proved that this task can not be efficiently undertaken by only one state.

To sum up, I can say that these potential disputes reaffirm the awareness of African states of the economic interest of the sea. Obviously, overlapping maritime claims will continue to increase in number in the following decades and this continent will also be facing the problems of disputes' resolution like the current event in Asian waters. Today, a state, be it a failed state or a civilized state, either a developed state or under developed state is not ready to concede to its neighbor a portion of empty land or a portion of land rich of natural resources. A third party dispute resolution often comply states to make such a concession although painfully. Therefore, why not develop the tradition of negotiation, mediation, conciliation in resolving a kind of dispute where disputed states have common economic interest? Moreover, natural resources are the 'gift of God', so when it comes to belong to different states, why not find out an alternative way to enjoy it friendly? In my view, Joint Development Agreements between states could help to come up to this end.

\subsection{African States Practice on Apprehending Maritime Resources Straddling on Their Boundaries}

The first practice or strategy to apprehend maritime resources in dispute by African states consists in denying the existence of boundary delimitation agreements between them on the disputed areas. And when it comes that they accept such an agreement, they challenge its binding force. The very imminent role that agreements play on dispute settlement between states brings international community to codify agreements on the basis of the law of treaty through the Vienna Convention on Law of the Treaties, 1969. Indeed, even in 1982 at the Montego Bay Conference, states did understand that agreements remain the best way of delimitation and dispute settlements either at international level or even at domestic level. That's why Article 83(4) UNCLOS, 1982 clearly assures that "where there is an agreement in force between the states in dispute, questions relating to the delimitation shall be determined in accordance with the provisions of that agreement." Perhaps, aware of this provision and in the case its application in a dispute may prevent a state from getting fully or in part the zone in dispute that African states challenge the existence of a boundary delimitation agreement or the binding force of such an agreement. However, this kind of practice didn't prevent the ICJ from granting the rich oil zone of Bakassi to Cameroon. Indeed, despite the challenge of Nigerian upon the existence or the binding force of territorial and maritime agreement between Nigeria and Cameroon, ICJ relied on the Anglo-German Demarcation Agreement of 11 March and 12 April 1913 [24], Yaoundé Declarations I \& II and the Maroua Declaration [25] contracted by and on behalf of the two countries to delimit territorial and maritime boundaries between Nigeria and Cameroon. Moreover, in Guinea-Bissau and Senegal dispute, the Tribunal did take into consideration 
the validity of a colonial boundary delimitation agreement to delimit maritime boundaries between these two states by recognizing that:

The Agreement concluded by an exchange of letters on 26 April 1960, and relating to the maritime boundary, has the force of law in the relations between the Republic of GuineaBissau and the Republic of Senegal with regard solely to the areas mentioned in that Agreement, namely the territorial sea, the contiguous zone and the continental shelf" [26].

Therefore, we could notice that the existence of a delimitation agreement has mostly served as a point of departure of third parties' dispute settlement. So, either a colonial agreement or agreement concluded between sovereign states, terrestrial or maritime, bilateral or multilateral, the existence of a boundary delimitation agreement has influenced the ICJ and Tribunals decisions. Despite this fact, the DRC is still standing on the rejection of a colonial treaty in its maritime boundary delimitation's dispute with Angola.

Another practice which is growing now in African maritime dispute consists in challenging the method of boundary line. While some coastal states stand for straight baseline delimitation, other contends that maritime boundary should be effected on the basis of median line. This is the current case between Somalia and Kenya on their maritime boundary delimitation dispute on the Indian Ocean. While Kenya is defending that this delimitation should be based on straight line, Somalia affirms that a straight line delimitation will threaten its sovereign rights, and thus stand for a delimitation based on median line according to UNCLOS Article 15 as far as it concerns their territorial sea limits, respectively Articles 74 and 83 for the limits of their EEZ and their CS. In fact, by doing so, Somalia could grab the rich oil disputed zone on which Kenya already leased eight offshore blocks to oil exploration companies and of which seven are located in the contested zone in the Indian Ocean. In addition, we have to notice that the problem becomes difficult to solve where natural resources are found to straddle the delimited maritime boundaries. In this case, even though there is an agreement prescribing the boundary line, African states do raise some interpretational challenges as if at the time they were concluding this agreement there was some misunderstanding upon the method used. By the way, if agreement should be understood as an act whereby the states in dispute upon a boundary decide, in writing, to demarcate their boundary based on specific delimitation method negotiated, acceptable and agreeable to them, can we then admit tacit boundary delimitation agreements in an area full of natural resources? The Ongoing dispute concerning delimitation of the maritime boundary between Ghana and Ivory Coast in the Atlantic Ocean before ITLOS seems to be an illustrative case which could help us deduce another tactic of African state to conquest maritime resources. In that case, Ghana is contending that there is a continuously agreed equidistance-based boundary delimitation line between Ghana and Ivory Coast since almost four decades without any protest from Ivory Coast. Or, in fact there is no written or formal agreement proving the existence of such a line though Ghana states that an Ivorian boundary delimitation law (1977) contends that Ivory Coast's maritime boundaries should be delimited either on median line or equidistance line. Ivory Coast has rejected such evidence by stating that the 1977 law is approximate and that the median line or the equidistance line mentioned on this law cannot presume a final delimitation of Ivory Coast's maritime boundaries with its neighbors. This law is not indefinite. It is considered as a provisional law. Therefore, by this way, Ivory Coast is claiming maritime boundary delimitation based on equitable principle. This principle could help Ivory Coast get access to maritime resources on the disputed zone where Ghana grants licenses to oil companies and is expecting its first production by 2016 . From this latter case, we could deduce the practice that consists of challenging equidistance line by equitable line. This trend is also adopted by Kenya and Somalia on their maritime boundary delimitation dispute actually pending before the ICJ. Thus, we could say that Somalia by asking a three-step delimitation procedure to the Court is claiming equitable-based maritime boundary delimitation while Kenya is defending equidistance-based line delimitation.

\subsection{The Issue of Mineral Resources'Presence in Disputed Area in Boundary Delimitation}

There is no need recalling the importance of mineral resources for the states. States need these resources not only as source of revenue for their nation but these resources could also help them release from energy dependence. Undoubtedly, the Court also understands this fact when it states in the Libya/Malta case, referring to mineral resources, that they "are the essential objective envisaged by States when they put forward claims to sea-bed areas containing them. [27]" However, with regard to this consideration, the issue which should be addressed by Court and Tribunals while proceeding on the merits upon maritime boundary delimitation is as followed:

Can the presence of mineral resources on disputed area influences a third-party's decision on maritime boundary delimitation? In other words, can the presence of maritime resources on a disputed zone be regarded or considered as a special circumstance while seeking an equitable result of boundary delimitation?

Despite the fact that the presence of mineral resources in a disputed zone constitutes a vital consideration in boundary delimitation dispute for the parties, the invocation of this fact seems not to convince the judges of ICJ and tribunals. This position is reasonable since modern international law does no more accept the rule of capture of mineral resource. Obviously, if the Court and Tribunals were to accept the relevance of the presence of mineral resources in disputed zones, states will gradually develop the right of capture of these resources by rushing and delivering licenses to operators to explore and exploit the latter while excluding or trespassing other potential parties' rights. However, the rejection of states' argument solely based on the presence of 
mineral resources as relevant circumstances in boundary delimitation is not absolute. It does depend on the way the claimant formulates its claim. Thus, ICJ's jurisprudence demonstrates that the claim built solely on the presence of mineral resources on the disputed zone may not be prosperous. Meanwhile, when the claim is built up by taking into consideration several factors including the presence of mineral resources on the disputed area, the Court seems to be convinced by the arguments of the claimant. This is the idea that the ICJ has opined in the North Sea Continental Shelf Cases when it asserts:

In fact, there is no legal limit to the considerations which States may take account of for the purpose of making sure that they apply equitable procedures, and more often than not it is the balancing-up of all such considerations that will produce this result rather than reliance on one to the exclusion of all others. The problem of the relative weight to be accorded to different considerations naturally varies with the circumstances of the case. Therefore, it could be contended that the main objective in boundary delimitation is to achieve an equitable delimitation and not an equal apportionment of maritime areas. Thus, when the sole consideration of the mineral resources' presence within the disputed area may entail an equal apportionment of this area, the relevance of the presence of mineral resources shouldn't be considered as such. Moreover, even the exploration or exploitation of mineral resources by concessionaires of states in dispute through could not serve as a solid relevant circumstance that could influence maritime boundary delimitation, except if these activities are carried on the basis of an express or a tacit agreement. The jurisprudence of ICJ provides evidence for this view in Nigeria/ Cameroon Case when it states that:

Overall, it follows from the jurisprudence that, although the existence of an express or tacit agreement between the parties on the siting of their respective oil concessions may indicate a consensus on the maritime areas to which they are entitled, oil concessions and oil wells are not in themselves to be considered as relevant circumstances justifying the adjustment or shifting of the provisional delimitation line. Only if they are based on express or tacit agreement between the parties may they be taken into account. In the present case there is no agreement between the Parties regarding oil concessions. The Court is therefore of the opinion that the oil practice of the Parties is not a factor to be taken into account in the maritime delimitation in the present case [28].

Again, remarkably, it should be noted that the exception of an express or a tacit agreement that is deemed to strengthen the presence of mineral resources on a disputed area as a relevant circumstance to be taken into account in maritime boundary delimitation seems not to be absolute. Indeed, in the phrasing of that exception as followed "Only if they are based on express or tacit agreement between the parties may they be taken into account", the Court used "may" rather than "should" which implies an obligation or a necessity whereas "may" is used to express permissibility of a fact.
Therefore, viewing the latitude left to the Court to consider this exception as relevant circumstance does explain the relativity of this exception. And, under this perspective, we could say that the Court does not take into consideration the conducts of states, or seemingly the Court is reluctant to consider states' conducts in maritime boundary delimitation. Moreover, in the case concerning the Delimitation of Maritime Areas between Canada and the French Republic (St. Pierre et Miquelon), the Tribunal concluded that it did not have a reason to consider the potential mineral resources as having bearing on the delimitation [29]. Nevertheless, it should be noted that ICJ's jurisprudence asserts that the presence of living resources in an area could be a determinant factor while tabling on a maritime boundary delimitation dispute. In fact, in the Greeland and Jan Mayen case, the ICJ did in fact take into account the presence of natural resources and divided the area in the way that the two Parties should enjoy equitable access to the fishing resources of this zone [30]. Hence, it should be noticed that the consideration of natural resources as a relevant circumstance in maritime boundary delimitation depends on the nature of maritime resources. Unlike to living resources, non-living resources, particularly mineral resources are subject to a relative appreciation of the Court before they could be considered as a relevant circumstance in maritime boundary delimitation.

Consequently, in order to reach an equitable delimitation, the presence of mineral resources which is one of the factors among others should be associated to other factors such as the physical and geological structure of the area in dispute, the general configuration of the coasts and the presence of any special or unusual features, and the element of a reasonable degree of proportionality.

\section{Concluding Remarks}

Just after independences, African states were facing instability due to the vagueness of their boundaries left to them by their former colonial powers. Thus, they wisely decided to keep these boundaries unchanged in order to restore peace and save it under the principle of inviolability of borders inherited from their colonial powers (hereafter called "principle of inviolability"). At the first glance, the principle of inviolability is closely intertwined with the manner in which the OAU decided to avoid armed conflicts over territorial claims and promote friendly relationship between African states, until a satisfactory and peaceful solution is found by the Parties to a territorial dispute in conformity with international law. This also encompasses their commitment to keep stability and unity among all African States through cooperation, particularly between neighboring states. In fact, under such a point of view, it could be rational to contend that this aim seems to fit with that of joint development on maritime resources through agreements in avoiding violence when negotiations between disputed states failed. Likewise, if African leaders intended 
to render boundaries less significant through the unification of the peoples of the continent in advocating the principle of inviolability, Joint Development Agreement (JDA) also focus more on maritime resources' development rather than maritime boundary dispute settlement. Furthermore, considering that 'the land dominates the sea' more than instructive, principle of inviolability can be imperious since the terrestrial delimitation could appear determinative in the delimitation of maritime boundary as we can notice in the aforementioned cases, notably those between Somalia and Kenya and Ghana- Ivory Coast. Even though the principle of inviolability is closely related to uti possidetis juris principle, the principle of inviolability does not provide a specific peaceful method or criterion to be used for ascertaining the pedigree of disputed boundaries. Intended to resolve disputes, the principle of inviolability does not specify any methods to be used for the peaceful settlement of boundary disputes. These disputes are left to be determined, on a case by case basis, by the states concerned. If this can be acceptable in terrestrial boundary determination, maritime boundary delimitation is regulated by UNCLOS. However, considering that the practice of ICJ and Tribunals demonstrate that not all relevant circumstances can be taken into account while delimiting maritime boundaries; one could assume that like in terrestrial boundary determination, maritime boundary delimitation seems to be done on a case by case basis. Nonetheless, what is clear in UNCLOS is that Articles 74 and 83 of UNCLOS call on states to effect delimitation through 'agreements'. Unfortunately, only few African states found out the wisdom to do so. Consequently, the application of the inviolability principle and the findings of agreements on boundary disputes result to the demarcation of only 30 percent of Africa's borders. And without being too much pessimist, I'd like to say that the rate of African maritime boundary issues will not increase if states do not stop displacing the symbols or monuments of borders' demarcation. This rate will remain unchanged as long as African states will continue challenging boundaries' delimitation principle that they have committed to respect. In fact, this is creating tension between countries seeking control of the region's natural resources, influencing political and international relations and triggering territorial disputes over maritime borders. Moreover, although the UNCLOS provides states the possibility to resolve a dispute peacefully through negotiation or other diplomatic measures, it is evident that these mechanisms mostly fail due to the existence of natural resources lying on the disputed zones. Lack of mutual trust between states could explain this failure in some extent. Reference to the ICJ or tribunals seems to be the last preference of African states while UNCLOS offers them a possibility to find out a practical arrangement to develop the zone while provisionally putting aside boundary delimitation issues. Therefore, African states would rather prevail 'practical arrangements' like JDA than the Court when we know that neither the implementation of the principle of inviolability nor the application of uti possidetis principle could help efficiently resolve a dispute on an area or a boundary full of natural resources. Although maritime claims must be consistent with international law, as well as the rights claimed by states within disputed maritime zones, JDA can be seen as one of the most suitable legal solutions that could help resolve conflicts on disputed maritime zones.

\section{References}

[1] Among these documents, we can cite: "Report of the United Nations Conference on Environment and Development, Rio de Janeiro, 3-14 June 1992, vol. I, Resolutions Adopted by the Conference (United Nations publication, Sales No. E.93. I. 8 and corrigendum), resolution 1, annex II"; "Report of the World Summit on Sustainable Development, Johannesburg, South Africa, 26August-4 September 2002(United Nations publication, Sales No. E.03. II. A. 1 and corrigendum), chap. I, resolution 2, annex" and "General Assembly resolution 66/288, annex".

[2] South Africa in 1930; Libya in 1951; Egypt, Morocco, Tunisia and Sudan in 1956 and Ghana in 1957. In addition it should be noted that Ethiopia and Liberia were free states and thus have never been colonized.

[3] Egypt, Sudan and Ethiopia.

[4] The Convention on the territorial sea and the contiguous zone, Apr.29, 1958, 516 U. N. T. S. 205; The Convention on the high seas, Apr. 29, 1958, 450 U. N. T. S.11; The Convention on the continental shelf, Apr. 29, 1958, 499 U. N. T. S. 311 and the Convention on fishing and conservation of the living resources of the high seas, Apr.29, 1958, 599 U. N. T. S. 285.

[5] African delegations made important contributions to the interests of international community. These interests can be seen through Part XI (international seabed area and the institutional framework for deep seabed mining) and Part XV (dispute settlement) whereas those concerning the interests of individual state can be seen through the wordings of Part $\mathrm{V}$ (EEZ), Part X (rights of access to the sea and freedom of transit of landlocked states), Part XII (protection and preservation of the marine environment), Part XIII (marine scientific research) and Part XIV (development and transfer of marine technology).

[6] Cameroon, Equatorial Guinea, Ethiopia and Tanzania.

[7] Democratic Republic of Congo and Ethiopia.

[8] Benin, Sierra Leone, Congo and Liberia.

[9] Morocco, Ghana, Gambia, Senegal, Cote d'Ivoire, Nigeria, Togo, Equatorial Guinea, Cameroon, Cape Verde, Gabon, Guinea Bissau, Mauritania, Sao Tome and Principe, Somalia and South Africa.

[10] Land and Maritime Boundary between Cameroon and Nigeria (Cameroon v. Nigeria), 2002 I. C. J. p.443, para.295, recalling the North Sea Continental Shelf Cases, n.3, para. 91.

[11] Amongst 86 States that attended to 1958 Geneva Conference 49 were developing countries (20 States from Latin America and 29 States from Africa and Asia).

[12] A. D. Martinez, "The Third United Nations Conference on the law of the Sea: prospects, expectations and realities", Journal of maritime law and commerce, vol. 7, $\mathrm{n}^{\circ} 1$, October 1975, p. 261. 
[13] The high seas being open to all nations, no State may validly purport to subject any part of them to its sovereignty. Freedom of the high seas is exercised under the conditions laid down by these articles and by the other rules of international law. It comprises, inter alia, both for coastal and non-coastal States: (1) Freedom of navigation; (2) Freedom of fishing; (3) Freedom to lay submarine cables and pipelines; (4) Freedom to fly over the high seas.

[14] North Sea Continental Shelf Cases, para. 85.

[15] Somalia institutes proceedings against Kenya with regard to "a dispute concerning maritime delimitation in the Indian Ocean", Paragraph 3 available at http://www.icjcij.org/docket/files/161/18360.pdf accessed on 3/09/2015.

[16] http://www.worldbulletin.net/ghana/145272/ivory-coast-takesmaritime-dispute-with-ghana-to-arbitration.

[17] See Case No 23 on Dispute Concerning Delimitation of the Maritime Boundary between GHANA and CÔTE D'IVOIRE in the Atlantic Ocean, Request for the prescription of provisional measures, Special Chamber of the International Tribunal for the Law of the Sea, 25 April 2015, available at https://www.itlos.org/fileadmin/itlos/documents/cases/case_no .23_prov_meas/C23_Order_prov.measures_25.04.2015_orig Eng.pdf accessed on 25/08/2015.

[18] https://www.stratfor.com/analysis/angola-drc-disputemaritime-boundary.

[19] http://menasborders.blogspot.com/2010/12/border-focusangola-and-drc.html.

[20] Common interest zones (CIZs), which can be established when a deposit is located on the maritime borders of two or more states, consist of an ad hoc arrangement for joint administration of the maritime area in question. On this basis, Angola created another CIZ in June 2003 with CongoBrazzaville, in which both countries agreed to share the revenues from the Lianzi oil field. "Champ pétrolier de Lianzi: plus d'un milliard de dollars pour l'exploitation", Journal de Brazza, 2 March 2012.

[21] "Zone pétrolière commune", Africa Energy Intelligence, no. 494, 22 September 2004.
[22] Lambert Mendé Omalanga, minister of hydrocarbon, approved it on 30 July 2007, and the National Assembly ratified it in November. Law 07/004 of 16 November 2007 authorising ratification of the agreement on the development and production of hydrocarbons in the maritime common interest zone signed by the DRC and Angola in Luanda, on 30 July 2007.

[23] http://www.irinnews.org/report/48239/gabon-equatorialguinea-un-mediates-dispute-over-corisco-bay-islands.

[24] Anglo- German Demarcation Agreements of 11 March and 12 April 1913 are negotiated and contracted by the two colonial states (with virtually no knowledge of the peoples and no respect of their traditional boundaries) but nonetheless respected on principle of inviolability of African borders inherited from their former colonial powers, which is mostly referred to the international law principle of utipossidetis by ICJ.

[25] The Maroua Declaration (1 June 1975) is the outcome of the meeting held at Maroua from May 30 to June 1, 1975 between Cameroon and Nigeria on their borders' delimitation issues. So, unlike to the Anglo-German Demarcation Agreements, the Maroua Declaration is negotiated by the two countries as sovereign states, having regained their political independence from their respective colonial powers in the early 1960s.

[26] 'Annex to the Application Instituting Proceedings of the Government of the Republic of Guinea-Bissau', Arbitral Award of 31 July 1989 (Guinea-Bissau v Senegal) [1989] ICJ Pleadings 1. 152-3 [88] (MrBarberis).

[27] Continental Shelf (Libya/Malta), Chap. 3, para. 50.

[28] Land and Maritime Boundary between Cameroon and Nigeria (Cameroon v. Nigeria), supra note 10, in Chap. 3, paras. 303-304.

[29] Delimitation of Maritime Areas between Canada and the French Republic (St. Pierre et Miquelon), 10 June 1992, Para. 89.

[30] Maritime Delimitation in the Area between Greenland and Jan Mayen, Paras. 75-76. 